\title{
MOTERŲ ŽINIOS APIE AROMATERAPIJOS NAUDĄ IR GALIMĄ ŽALĄ NËŠTUMO LAIKOTARPIU
}

\author{
Diana Barragan Ferrer, Viktorija Bražukaitytė \\ Kauno kolegija, Medicinos fakultetas
}

Raktažodžiai: aromaterapija, nèštumas, eteriniai aliejai.

\section{Santrauka}

Aromaterapija yra puiki priemonè mažinti gimdymo skausmą, ịveikti fiziologinius nèštumo ir ankstyvosios motinystès rūpesčius bei diskomforto pojūtį. Nors tai gan saugus terapijos būdas, néččiosioms privalu aromaterapiją ir eterinius aliejus rinktis atidžiai, kad apsaugotų save ir vaisių nuo galimo žalingo poveikio. Mokslinèje literatūroje yra duomenų, kad kai kurie eteriniai aliejai gali sukelti spazmus, paveikti kraujotakos sistemą. Populiarejjant aromaterapijos taikymui nèštumo periodu, kyla klausimas, ar moterys pakankamai žino apie aromaterapijos naudą ir galimą žalą. Tyrimo tikslas - atskleisti moterų žinias apie aromaterapiją něščiosioms, jos naudą ir galimą žalą. Tyrimui atlikti pasirinkta anketinè apklausa. Atlikus anketinę apklausą ir ịvertinus rezultatus atskleista, kad įvairaus amžiaus moterys (nepriklausomai nuo išsilavinimo) yra naudojusios (naudoja) aromaterapiją ar aromaterapinius produktus. Tyrime dalyvavusios moterys daugiau žinojo apie savarankišką eterinių aliejų naudojimą, negu apie aromaterapijos saugumo reikalavimus nèštumo laikotarpiu. Kas penkta apklausos dalyvė nežinojo apie aromaterapijos naudą ir néččiujų diskomfortą keliančias problemas, kurias aromaterapijos taikymas gali sumažinti ar net visiškai pašalinti. Tyrime dalyvavusios respondentès jaučia informacijos apie aromaterapiją néštumo metu trūkumą ir mano, kad apie ją žinoti daugiau yra naudinga.

\section{Ivadas}

Aromaterapijoje naudojami eteriniai aliejai yra koncentruoti, išgaunami iš augalų, medžių, jų šaknų, vaisių, lapų, stiebų, žievès, odelių, žiedlapių, kurių savybės yra naudingos sveikatai, todèl naudojamos fizinèms ir psichologinèms problemoms spręsti [1]. Augalų aromatai naudojami bendrai organizmo savijautai gerinti, veikia antiseptiškai, baktericidiškai, turi uždegimo slopinamaji poveiki, teigiamai veikia žmogaus nervų sistemą, palaiko organizmo savireguliacijos procesą [2]. Nepaisant teigiamų eterinių aliejų savybių, netinkamas jų naudojamas, per didelè koncentracija, nenatūralūs, nekokybiški aliejai, neatsižvelgimas ị organizmo jautrumą, saugojimo ir laikymo taisyklių nepaisymas gali sukelti nepageidaujamą efektą. Eterinių aliejų toksiškumas gali sudirginti odą, sukelti alergines reakcijas, fototoksini efektą, persileidimą ir kt. [3]. Nèštumo laikotarpiu būtina aromaterapiją ir eterinius aliejus rinktis ir dozuoti atidžiai ir atsargiai, siekiant apsaugoti save ir vaisių, nes kai kurie eteriniai aliejai gali sukelti spazmus ar stipriai paveikti kraujotakos sistemą [4].

Jau daugelį metų aromaterapija ir masažai efektyviai taikomi visą nëštumo laikotarpị, nes kai kurių vaistų vartojimas něščiosioms yra griežtai draudžiamas dèl galimo neigiamo poveikio vaisiui. Aromaterapija yra švelnesné priemoné, leidžianti pagerinti moters savijautą tiek prieš gimdymą, tiek gimdymo metu ar po jo, nes eteriniai aliejai padeda ịveikti ar sušvelninti daugelị fizinių ir emocinių pojūčių bei simptomų [5].

Pastaraisiais dešimtmečiais aromaterapija plačiau taikoma néččiosioms ir neseniai pagimdžiusioms moterims. Dalis akušerių apie aromaterapiją ir jos naudą gimdyvėms kalba drąsiai, rekomenduoja ir naudoja visokeriopai něščiosios priežiūrai. Tai puiki priemonè mažinti gimdymo skausmą, palengvinti fiziologinius nëštumo ir ankstyvosios motinystès rūpesčius bei diskomforto jausmą. Néščiosios priežiūrai naudojant eterinius aliejus, papildoma ịprastinè priežiūra prieš gimdymą, gimdymo metu ar po gimdymo, pradedant nuo pastojimo pradžios iki 28 dienų po gimdymo, kai pasibaigia akušerių priežiūros laikotarpis [5].

Aromaterapijos specialistai, išmanantys nėččiosios kūno anatomijos ir fiziologijos pokyčius, bendradarbiaudami ir tardamiesi su jos priežiūra besirūpinančia kvalifikuota komanda, gali patarti naudoti tam tikrus eterinius aliejus. Akušerès, užsiimančios privačia aromaterapijos praktika, turètų pranešti vietos priežiūros institucijai, jei ketina nėščiosios sveikatą gerinti eterinių aliejų pagalba. 
Nors kai kurie aromaterapeutai nėščiosioms nenaudoja emenagoginių ar abortinių savybių turinčių eterinių aliejų, realus pavojus kyla tuo atveju, jei šių aliejų bus naudojamas per didelis kiekis ar koncentracija. Svarbu žinoti, kad pirmuosius tris něštumo mènesius vaisius yra ypač jautrus ir pažeidžiamas cheminių medžiagų poveikio. Yra tyrimų, kurie įrodo, kad skirtingos vaisiaus sistemos tam tikru metu yra jautrios skirtingoms cheminėms medžiagoms [5].

Něštumo metu vengiama emenagoginių eterinių aliejų, skatinančių ir reguliuojančių menstruacijas, todèl šiu savybių turinčių aliejų vengiama iki pirmojo trimestro pabaigos, kai moteris supranta esanti néščia. Tokie eteriniai aliejai aromaterapijoje yra plačiai naudojami gydyti policistines kiaušides, dismenorèją, amenorejją ir priešmenstruacinę įtampą (sindromą), todèl jų reikètų vengti viso nèštumo metu [5].

Moterys vis dažniau renkasi eterinius aliejus nėštumo metu, tačiau jų pasirinkimą dažniausiai lemia produkto kvapas, todèl kyla klausimas, ar jos turi pakankamai žinių apie aromaterapijos naudą ir galimą žalą néštumo periodu?

Tyrimo tikslas - atskleisti moterų žinias apie aromaterapijos naudą ir galimą žalą néščiosioms.

\section{Tyrimo objektas ir metodika}

Tyrimo priemone pasirinkta internetinè anoniminè anketa, kurią sudare 17 klausimų. Visi klausimai buvo uždaro tipo, su vienu arba keliais galimais atsakymo variantais. Tyrimo dalyvès atrinktos tikimybinès paprastosios atsitiktinès imties būdu. Tyrime dalyvavo 106 respondentès. Didžiosios dalies respondenčių amžius buvo 18-25 (56 proc.) ir 2634 (25 proc.) metai. Kiekviena tyrimo dalyvè anonimineje apklausoje sutiko dalyvauti laisva valia. Prieš tyrimą visos respondentès buvo supažindintos su tyrimo tikslu, informuotos apie anonimiškumą, paaiškinta, kad rezultatai bus viešinami tik apibendrinti, be galimybės identifikuoti atskirus respondentus.

\section{Tyrimo rezultatai}

Aromaterapija turi labai plačią pritaikymo ir būdų ịvairovę. I klausimą, kurio tikslas išsiaiškinti moterų žinias apie aromaterapijos būdus, respondentès galèjo pasirinkti kelis atsakymo variantus. Gauti apklausos duomenys parodè, kad žinomiausi aromaterapijos būdai yra inhaliacijos, aromatinès vonios, masažai bei garinimas. Kompresai, naudojimas i vidų ir tiesiogiai ant odos yra mažiau žinomi aromaterapijos būdai. Tik 4 proc. apklaustujų apie aromaterapijos būdus nieko nežinojo (1 pav.).

Nors dauguma moterų žino įvairius aromaterapijos būdus, tačiau paklausus apie aromaterapijos saugumo reikalavimus néštumo metu, 68 proc. apklaustujjų nieko apie juos nežinojo. Aromaterapijoje galima naudoti įvairius produktus.
Labiausiai žinoma medžiagų rūšis yra eteriniai aliejai, jie nuo seno atlieka ypač svarbų vaidmeni žmonių gyvenime [6]. Siekiant išsiaiškinti, ar moterys žino skirtingas aromaterapijoje naudojamų medžiagų rūšis, paaiškejo, kad nedidelè dalis moterų žinojo apie žolelių hidrolatus ir distiliatus bei užpilus. Apie absoliutų ir fitoncidų naudojimą žinojo tik $10-19$ proc. respondenčių (2 pav.).

Eterinius aliejus reikia naudoti atsakingai, laikantis saugumo reikalavimų, ypač tada, kai jie naudojami savarankiškai [7]. Daugiau nei pusè respondenčių žinojo, kad savarankiškai naudojant eterinius aliejus, reikia laikytis šiu saugumo reikalavimų: draudžiama naudoti vaikams be suaugusiojo priežiūros; eterinių aliejų nenaudoti ant pažeistos odos; eterinių aliejų nenaudoti akių zonoje; esant alergijai ar jautrumui, atlikti odos lopinèlio testą. Mažiau nei pusè atsakiusiujų žinojo, jog eterinius aliejus reikia rinktis atsakingai, tik geros kokybès, laikyti tamsioje vietoje. Mažiausiai apklausos dalyvių žinojo, kad nèštumo metu galima naudoti tik 1 procento skiedinị (3 pav.).

Saugus aromaterapijos naudojimas gali numalšinti ar palengvinti daugeli néštumo metu patiriamų simptomų. 66 proc. apklaustujų žinojo, kad aromaterapija nėštumo laikotarpiu mažina gimdyvès patiriamą stresą. Atlikto tyrimo, kurio metu nėččiosioms buvo taikomi aromaterapiniai masažai su levandų eteriniu aliejumi, rezultatai parodè, jog tiriamujų seilèse sumažejo kortizolio ir padidejjo IgA kiekis [8]. Tai reiškia, jog aromaterapija mažina néščiujų patiriamą stresą laukimo metu. Pusė apklausoje dalyvavusių moterų žinojo, kad naudojant aromaterapiją, nerimo ir galvos skausmo simptomai gali būti sumažinti ar net visiškai numalšinti. Literatūroje teigiama, kad tinkamai parinkti eteriniai aliejai gali pagerinti něščiosios nuotaiką, mažinti depresiją ar nerimo sukeltą kraujospūdị [9]. Nedidelė dalis moterų žinojo, kad aromaterapija gali mažinti raumenų skausmą, odos problemas, vẻmimą ir pykinimą, nugaros, dubens skausmus, aukštą kraujospūdị, varikozę, hemorojų ar net gimdymo skausmą. Net 20(19 proc.) apklausos dalyvių neturejjo žinių apie problemas, kurias gali išspręsti aromaterapija nèštumo metu. Viena apklausos dalyvė prie pateiktų atsakymų pridejo savo variantą - „žemas kraujo spaudimas“ (4 pav.).

Daugiau nei pusé apklausos dalyvių žinojo, kad netinkamai naudojami eteriniai aliejai něštumo metu gali sukelti nepageidaujamas alergines reakcijas dẻl juose esančių oksiduotų komponentų [6]. 39 proc. moterų žinojo, kad jie gali sukelti odos sudirgimą. Nedidelè dalis žinojo, jog netinkamai naudojami eteriniai aliejai něštumo metu gali sukelti toksinị poveikį kepenims, bronchų hiperaktyvumą, sulètinti ar sutrikdyti vaisiaus vystymąsi, sukelti neurotoksiškumą, fototoksiškumą, priešlaikinį gimdymą ar savaimini persileidimą. 42 proc. respondenčių apie tokią galimą žalą nežinojo (5 pav.). 
Tikrinant moterų žinias apie eterinius aliejus, kurių naudojimas néštumo metu draudžiamas, buvo pateikti dešimt atsakymo variantų (penki draudžiami ir penki galimi naudoti eteriniai aliejai). Atsakymų rezultatai parodè, kad moterys žino, jog kadagio, rozmarino, kamparo, gvazdikèlio ir baziliko eterinius aliejus draudžiama naudoti něštumo metu. Dalis atsakiusiujų kaip draudžiamus rinkosi greipfruto, levandos, arbatmedžio, citrinos ir apelsino eterinius aliejus,

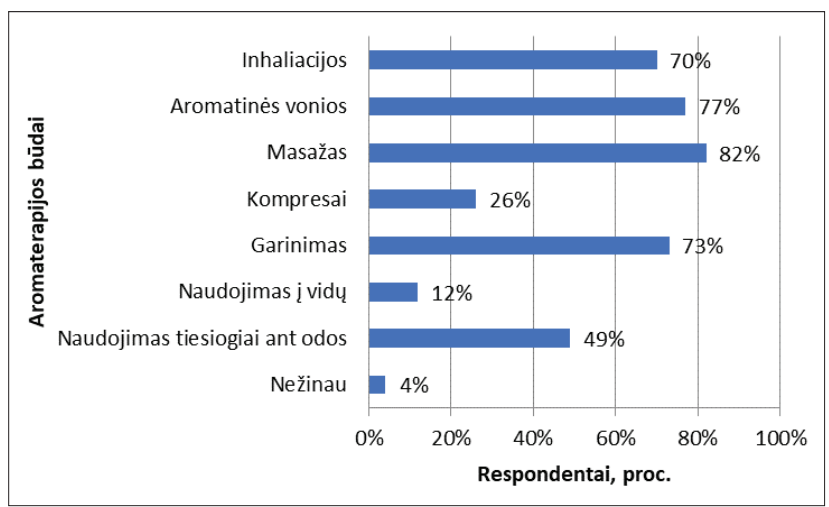

1 pav. Respondenčių žinios apie aromaterapijos būdus $(\mathrm{N}=106)$

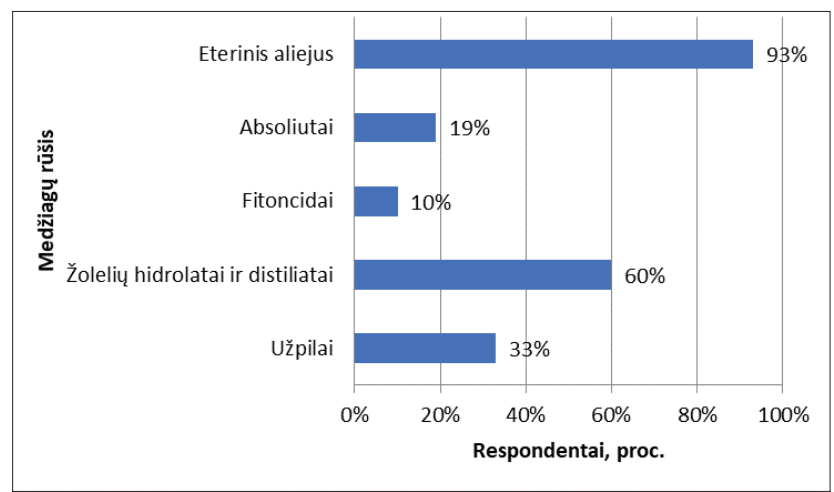

2 pav. Respondenčių žinios apie aromaterapijoje naudojamas medžiagų rūšis $(\mathrm{N}=106)$

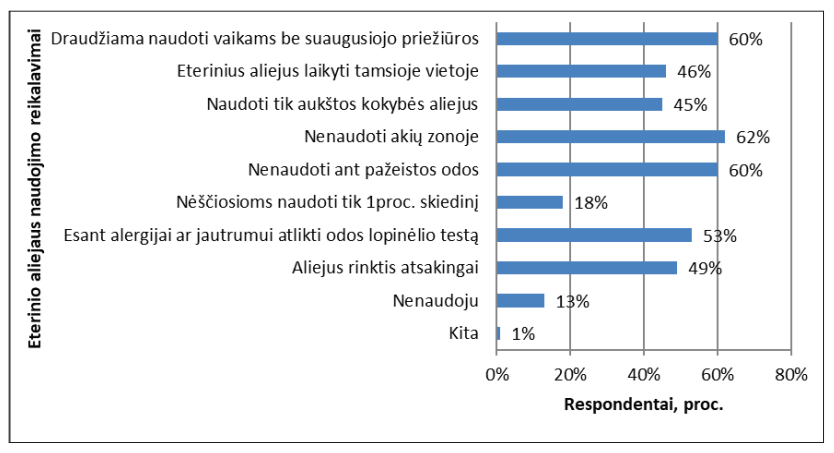

3 pav. Respondenčių žinios apie savarankiško eterinių aliejų naudojimo reikalavimus $(\mathrm{N}=106)$ nors jie yra saugūs naudoti nėštumo periodu (6 pav.).

Anketos pabaigoje buvo užduota papildomų klausimų, siekiant išsiaiškinti, ar moterims pakanka informacijos apie aromaterapiją ir jos taikymą něštumo periodu. 100 apklausos dalyvių atsakè, jog jaučia informacijos apie aromaterapiją

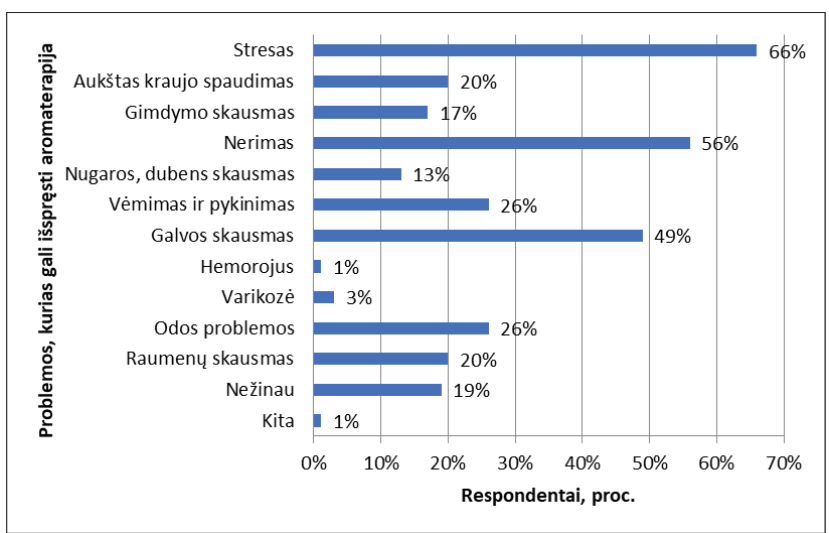

4 pav. Respondenčių žinios apie problemas, kurias gali išspręsti aromaterapija nëštumo laikotarpiu $(\mathrm{N}=106)$

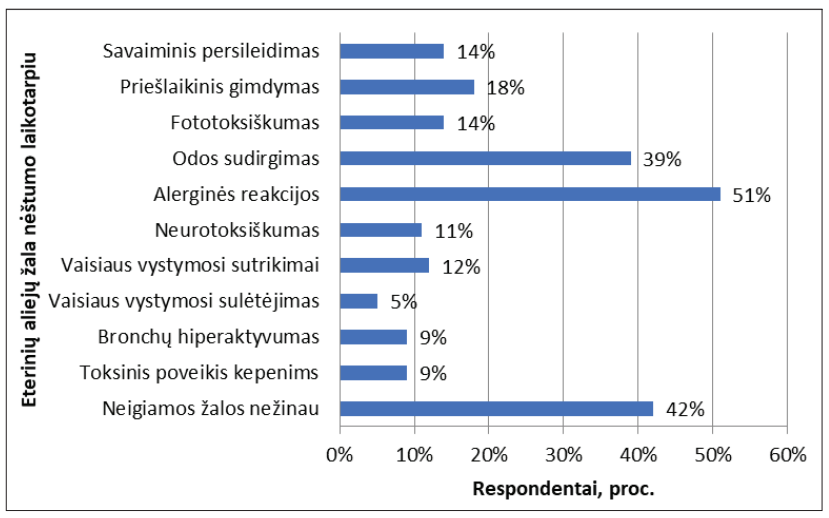

5 pav. Respondenčių žinios apie galimą eterinių aliejų žalą nėštumo laikotarpiu $(\mathrm{N}=106)$

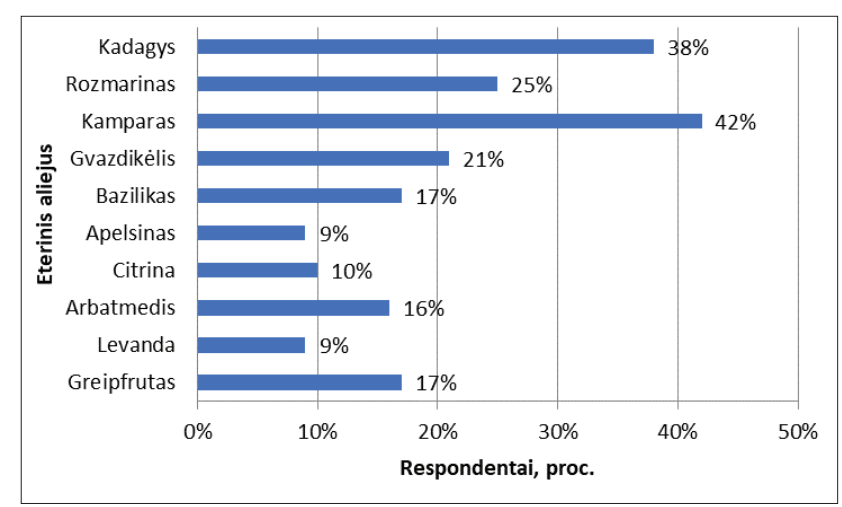

6 pav. Respondenčių žinios apie nerekomenduojamus naudoti eterinius aliejus nėštumo laikotarpiu $(\mathrm{N}=106)$ 
nėštumo metu trūkumą. Didžioji dalis (93 proc.) apklausos dalyvių atsakè, kad norètų daugiau sužinoti apie aromaterapijos naudojimą néštumo laikotarpiu.

\section{Išvados}

1. Aromaterapija ir jai naudojami produktai turi platu panaudojimo galimybių spektrą. Jie naudojami fizinèms bei psichologinèms problemoms spręsti. Nèštumo laikotarpiu aromaterapija gali padèti malšinti ar šalinti tokius negalavimus, kaip stresas, aukštas kraujospūdis, nugaros, dubens skausmai, vėmimas, pykinimas ir kt. Aromaterapijai naudojami eteriniai aliejai būtų ne gryni, o praskiesti iki 1 procento.

2. Apibendrinus tyrimo rezultatus nustatyta, kad didžioji dalis moterų žino, kas yra aromaterapija, tačiau joms trūksta žinių apie aromaterapijos taikymą něštumo laikotarpiu. Moterys nesusipažinusios su aromaterapijos saugumo reikalavimais, eterinių aliejų saugumo veiksniais bei problemomis, kurias gali išspręsti ar sukelti aromaterapija.

\section{Literatūra}

1. Scott J, Harrison A. Spa: The Official Guide to Spa Therapy at Levels 2 \& 3: Levels 2 and 3. Habia City \& Guilds 2006.

2. Zlatkuvienè S. SPA procedūros grožio terapijoje. Kaunas, 2012.

3. Vaikšnorienè V. Aromaterapijos pagrindai. Kaunas: Kauno kolegijos leidybos centras, 2006.

4. Agnew T, Leach M, Segal L. The clinical impact and cost-effectiveness of essential oils and aromatherapy for the treatment of acne vulgaris: a protocol for a randomized controlled trial. Journal of alternative and complementary medicine. New York 2014;20(5):399-405. https://doi.org/10.1089/acm.2013.0137

5. Price S, Price L. Aromatherapy for health professionals 4th Edition. 2011.

6. Asay K, Olson C, Donnelly J, Perlman E. The Use of Aromatherapy in Postoperative Nausea and Vomiting: A Systematic Review. J Perianesth Nurs 2019;34(3):502-516.

https://doi.org/10.1016/j.jopan.2018.08.006

7. de Groot AC, Schmidt E. Essential Oils, Part I: Introduction. Dermatitis 2016;27(2):39-42.

https://doi.org/10.1097/DER.0000000000000175
8. Chen PJ, Chou CC, Yang L, Tsai YL, Chang YC, Liaw JJ. Effects of Aromatherapy Massage on Pregnant Women's Stress and Immune Function: A Longitudinal, Prospective, Randomized Controlled Trial. The Journal of Alternative and Complementary Medicine 2017;23(10):778-786.

https://doi.org/10.1089/acm.2016.0426

9. Namazi M, Amir Ali Akbari S, Mojab F, Talebi A, Alavi Majd $\mathrm{H}$, Jannesari S. Aromatherapy with citrus aurantium oil and anxiety during the first stage of labor. Iran Red Crescent Med J 2014;16(6):e18371.

https://doi.org/10.5812/ircmj.18371

\section{WOMEN'S KNOWLEDGE OF AROMATHERAPY DURING PREGNANCY, ITS BENEFITS AND POTENTIAL HARMS \\ D. Barragan Ferrer, V. Bražukaitytė}

Keywords: aromatherapy, pregnancy, essential oils.

Summary

Aromatherapy is recognized as a therapeutic alternative to help women reduce their physiological stress during pregnancy and cope with the pain during childbirth. However, with an increase in the popularity of this safe method as a treatment for pregnant women, attention should be paid to the choice of essential oils. This prudent decision should be based on possible detrimental effects, for example, on the blood circulation system or spam. Thus, the aim was to evaluate the level of understanding of the effects of aromatherapy for this group of women. A questionnaire survey was chosen for the present study. The survey showed that women of all ages have used, are using aromatherapy (regardless of education level). The results also showed that women know how to use essential oils, but they are often unaware of the health risks associated with their use. It was observed that one in five of these women ignore both the significant benefits and the health risks. Finally, there is general agreement among all respondents that there is a lack of information about the effects related to the use of essential oils. Also, they wish to further their knowledge about the use of these oils.

Correspondence to: diana.barragan.ferrer@go.kauko.lt

Gauta 2021-09-06 